$$
\operatorname{CONF}-971241-1
$$

\title{
Secondary Mineral Evidence of Large-Scale Water Table Fluctuations at Yucca Mountain, Nye County, Nevada
}

\author{
By J.F. Whelan', R.J. Moscati', Edwin Roedder', and B.D. Marshall' \\ ' Yucca Mountain Project Branch, U.S. Geological Survey, Denver, Colorado \\ - 2 Dept. Earth and Planet. Sci, Harvard University, Cambridge, Massachusetts
}

RECEIVED

At Yucca Mountain, which is currently under consideration as a potential permanent underground repository for high-level radioactive wastes, the present-day water table is 500 to $700 \mathrm{~m}$ deep (Luckey et al., 1996). This thick unsaturated zone (UZ) is part of the natural barrier system and is regarded as a positive attribute of the potential site.

The USCS has studied the stable isotopes and petrography of secondary calcite and silica minerals that coat open spaces in the UZ and form irregular veins and masses in the saturated zone (SZ) (Szabo and Kyser, 1990; Whelan et al., 1994). These studies have revealed a thick barren zone in which secondary mineral occurrences are rare. This barren zone extends from about $100 \mathrm{~m}$ above to more than $300 \mathrm{~m}$ below the present water table (fig. 1). Shallow ground waters beneath Yucca Mountain are undersaturated with respect to calcite (Benson and McKinley, 1985) and have the potential to dissolve calcite along active flowpaths in this interval. The rare occurrences of secondary calcite in this barren interval appear to have formed at times when the water table was much lower than at present.

Strontium isotope studies of secondary calcite within Yucca Mountain (Marshall et al., 1993), and regional analysis of ground water discharge deposits indicate that water table elevations were higher in the past (Quade et al., 1995). Discharge deposits at paleospring sites in southern Crater Flat, 15 to $20 \mathrm{~km}$ southwest of Yucca Mountain, indicate at least a $100 \mathrm{~m}$ rise in the water table during the late Pleistocene (Paces et al., 1997). Past water table rises beneath Yucca Mountain of -100 $\mathrm{m}$ are likely and a possible explanation for the paucity of secondary minerals within the lower UZ, although $\mathrm{Ca}$ depletion in the zeolitic tuffs through cation exchange may produce calcite undersaturation of percolating waters. Only drillhole USW G-2 contains significant amounts of calcite within the lower $100 \mathrm{~m}$ of the UZ.

Drusy coatings of free-growing calcite and silica phases formed in the UZ from surface percolation fluxes moving down fracture footwalls and, locally, collecting on the floors of lithophysal cavities. Most UZ calcite $\delta^{13} C$ values, which are generally between -9 and $+2 \%$, indicate derivation of solutes from the overlying soils during infiltration (fig. 1). Local occurrences of early calcite from $U Z$ exposures in drill core and the Exploratory Studies Facility have anomalously heavy $\delta^{13} \mathrm{C}$ values (as high as $9 \%$ ) that are inconsistent with soil organic matter as the sole carbon source.

Figure 1. Stable $\mathrm{C}$ and $\mathrm{O}$ isotopic compositions of calcite, plotted with respect to the water table, from boreholes collared on the crest or eastem flank of Yucca Mountain. Fields discussed in text are outlined and labeled.

DISTRIBUTION OF THIS DOCUMENT IS UNURHITED ho

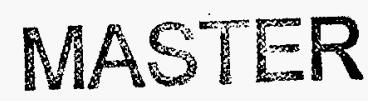


Textures and compositions of calcite occurrences from deep in the SZ are distinctly different from those in the UZ. Deep SZ calcite occurs as tightly intergrown crystal masses that filled existing open spaces, replaced phenocrysts, and formed pore-filling cements. This $S Z$ mineralization appears to have formed from moderate temperature alteration of the tuffs (Broxton et al., 1987) by Paleozoic ground waters that introduced calcite with $\delta^{13} \mathrm{C}$ values of $0 \pm 2 \%$ (Whelan et al., 1994). Timing of alteration is consistent with the formation of the Timber Mountain caldera (Bish and Aronson, 1993).

Secondary mineral occurrences formed in the $U Z$ and the $S Z$ are distinguished by the following characteristics:

(1) Textures/mineralogy - UZ calcite occurs as free-growing crystals, with patchy chaicedony or drusy quartz in the early stage and with opal in the later stages. Alteration-event calcite, locally with banded chalcedony and quartz, formed interlocking crystal mosaics that filled SZ open spaces.

(2) UV fluorescence/phosphorescence - Early UZ calcite does not fluoresce or phosphoresce nor does later calcite found at depth in the $U Z$; late $U Z$ calcite fluoresces and phosphoresces bright white in occurrences from the near surface. Alteration-event calcite fluoresces bright orange but does not phosphoresce.

(3) Cathodoluminesence - Calcite from the UZ generally does not luminesce but locally contains thin, irregular growth bands that luminesce faintly to moderately orange. Alteration-event calcite invariably luminesces a fiery bright orange.

(4) Fluid inclusions - Calcite from the $U Z$ has fluid inclusions that are typically single-phase, either all-liquid or all-vapor, indicative of entrapment in a UZ setting (Roedder et al., 1994). Alteration-event calcite contains dominantly two-phase inclusions indicative of moderate-temperature $\left(94\right.$ to $\left.239^{\circ} \mathrm{C}\right), \mathrm{SZ}$ mineral growth (Bish and Aronson, 1993).

(5) Strontium isotopes ${ }^{87} \mathrm{Sr} /{ }^{86} \mathrm{Sr}$ ratios of calcite samples display slightly overlapping ranges of 0.7096 to 0.7127 in the $U Z$ and 0.7086 to 0.7098 in the SZ, and do not clearly differentiate between the UZ and SZ (Marshall et al., 1993).

Anomalous barren zone calcite occurrences from the upper $S Z$ are outlined on figure 1 . These anomalous occurrences range in depth from about 140 to about $300 \mathrm{~m}$ below the present water table and generally resemble UZ calcite because they: (1) are free-growing; (2) do not fluoresce or phosphoresce; (3) locally display orange growth banding but are largely nonluminescent; and (4), based on preliminary fluid inclusion observations, formed below $-50^{\circ} \mathrm{C}$ in a vadose setting. Finally, (5) the ${ }^{87} \mathrm{Sr} / 86 \mathrm{Sr}$ ratios of the calcite from these anomalous occurrences range from 0.7094 to 0.7104 ; although not definitive, these ratios are similar to the bulk rock compositions of the host rocks and could form during UZ conditions.

Based on these observations, the anomalous secondary mineral occurrences from the upper SZ appear to have formed under UZ conditions - lower water table elevations in the past is the most straightforward mechanism to explain an UZ setting at these depths. Other explanations involve movement of the tuff sequence relative to a more or less static water table position. For instance, past rates of tectonic uplift are unclear, as is the rate of isostatic crustal depression following eruption of the tuff sequence. Conceivably, such processes could have raised the tuff sequence with respect to a static water table.

The $\delta^{13} \mathrm{C}$ values of the anomalous occurrences range widely from almost $-10 \%$ to nearly $+5 \%$. This range is comparable to the entire range of secondary calcite $\delta^{13} \mathrm{C}$ values recorded by the more than $9 \mathrm{M} . \mathrm{y}$. mineralization history of the UZ. The range of $\delta^{13} \mathrm{C}$ values in this anomalous interval, therefore, may be evidence of more than one period of significantly lowered water table elevation.

Benson, L.V., and McKinley, P.W., 1985, Chemical composition of ground water in the Yucca Mountain area, Nevada, 1971-84: U.S. Geological Survey Open-File Report 85-484, 10 p.

Bish, D.L., and Aronson, I.L., 1993, Paleogeothermal and paleohydrologic conditions in silicic tuff from Yucca Mountain, Nevada", Clays and Clay Minerals, 41, 148-161 (1993).

Broxton, D.E., D.L. Bish, and R.G. Warren, 1987, Distribution and chemistry of diagenetic minerals at Yucca Mountain, Nye County, Nevada: Clays and Clay Minerals, v. 35, p. 89-110.

Marshall, B.D., Peterman, Z.E., and Stuckless, J.S., 1993, Strontium isotopic evidence for a higher water table at Yucca Mountain: in In'l' High-Level Radioact. Waste Man. Proc., ASCE and ANS, 4th Internat. Conf., Las Vegas, Nevada, p. 1948-1952.

Luckey, R.R., Tucci, P., Faunt, C., Ervin, E., Steinkamp, W., D'Agnese, F. and Patterson, G., 1996, U.S. Geol. Survey Open-File Rept 96-4077, 71 p.

Paces, J.B., Peterman, Z.E., Neymark, L.A., Whelan, J.F., and Marshall, B.D., 1997, Proceedings, OECD/NEA Workshop on Use of Hydrochemical Information in Testing Groundwater Flow Models, Borgholm, Sweden, 1-3 Sept., 1997, p. 69-71. 


\section{DISCLAIMER}

This report was prepared as an account of work sponsored by an agency of the United States Government. Neither the United States Government nor any agency thereof, nor any of their employees, makes any warranty, express or implied, or assumes any legal liability or responsibility for the accuracy, completeness, or usefulness of any information, apparatus, product, or process disclosed, or represents that its use would not infringe privately owned rights. Reference herein to any specific commercial product, process, or service by trade name, trademark, manufacturer, or otherwise does not necessarily constitute or imply its endorsement, recommendation, or favoring by the United States Government or any agency thereof. The views and opinions of authors expressed herein do not necessarily state or reflect those of the United States Government or any agency thereof. 
Quade, J., Mifflin, M.D., Pratt, W.L., McCoy, W., and Burckle, L., 1995, Spring deposits and water table levels in the southern Great Basin during the Quaternary: Geol. Soc. Amer. Bulletin, v. 107, p. $213-$ 230.

Roedder, Edwin, J.F. Whelan, and Vaniman, D.T., 1994, Fluid inclusion homogenization and crushing studies of calcite veins from Yucca Mountain, Nevada, Tuffs: Environment of formation: in Int'I High-Level Radioact. Waste Man. Proc., ASCE and ANS, 5th Internat. Conf., Las Vegas, Nevada, p. 1854-1860.

Szabo, B.J., and Kyser, T.K., 1990, Ages and stable-isotope compositions of secondary calcite and opal in drill cores from Tertiary volcanic rocks of the Yucca Mountain area, Nevada; Geol. Soc. Amer. Bulletin, v. 102, p. 1714-1719.

Whelan, J.F., Vaniman, D.T., Stuckless, J.S., and Moscati, R.J., 1994, Paleoclimatic and paleohydrologic records from secondary calcite: Yucca Mountain, Nevada: in Int'l High-Level Radioact. Waste Man. Proc., ASCE and ANS, 5th Internat. Conf., Las Vegas, Nevada, p. 2738-2745. 


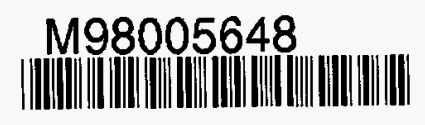

Report Number (14) CONF-97/241--1

Publ. Date (11) $1997 / 2$

Sponsor Code (18) USGS, XF

UC Category (19) UC-000, DOElER

\section{0}

TILC QUATITH INOPECTIBD 1 